\title{
Proximate Nutritional Analysis and Heavy Metal Composition of Dried Moringa Oleifera Leaves from Oshiri Onicha L.G.A, Ebonyi State, Nigeria
}

\author{
Offor, I.F. ${ }^{1 *}$, Ehiri, R.C. ${ }^{1}$, Njoku, C.N ${ }^{2}$ \\ ${ }^{1}$ Department of Chemistry, Federal University Ndufu Alike, Ikwo, P.M.B. 1010, Abakaliki, Ebonyi State, \\ Nigeria \\ ${ }^{2}$ Department of Industrial Chemistry, Ebonyi State University, P.M.B. 053, Abakaliki, Ebonyi State, Nigeria
}

\begin{abstract}
To carry out proximate analysis and heavy metal assessment of dried moringa leaves in order to ascertain their nutritional and metal content values. Fresh leaves of moringa oleifera lam were plucked from moringa trees growing at Egbooda, Oshiri in Onicha area of Ebonyi State, Nigeria. The period of sampling was for 2 weeks in the month of March, 2013. The leaves were air dried at room temperature and their proximate contents determined using standard analytical techniques. Ash and moisture contents were determined using the Association of Official Analytical Chemists (AOAC) method. Fat, crude fibre and protein content were determined using soxhlet fat extraction method, weende's method and kjeldahl method respectively. In addition, carbohydrate content was determined using arithmetic difference method. Results show that the mean nutritional content of the samples were: $24.5 \%$ protein, $14.8 \%$ moisture, $17.3 \%$ crude fibre, $4.5 \%$ Fat, Ash $3.8 \%$ Ash and 50.6\% carbohydrate. Heavy metal composition was assessed using spectrophotometric and ethylenediaminetetraacetic acid (EDTA) titrimetric methods. The results indicated that Ca and Cd were not detected in the leaf samples. The metal contents in the leaves were Fe (505 mg/L), Zn (85,810.951 mg/L), Cu $(1.016 \mathrm{mg} / \mathrm{L}), \mathrm{Mg}(386.555 \mathrm{mg} / \mathrm{L}), \mathrm{Mn}(79.563 \mathrm{mg} / \mathrm{L})$ and $\mathrm{Pb}(352.013 \mathrm{mg} / \mathrm{L})$.
\end{abstract}

Keywords ; leaves, moringa oleifera, nutritional value, proximate analysis

\section{INTRODUCTION}

Moringa Oleifera belongs to the monogeneric family of shrubs and trees, called Moringaceae [1]. The tree originated from Agra and Qudh in Northwestern region of India, South of the Himalayan Mountain. The tree has spread to almost all tropical belt because it is drought- resistant [2]. Also, the leaves, fruits, flowers and immature pods are edible and they form part of traditional diets in many countries of the tropics and sub-tropics [3]. The oil obtained from the seeds is pale yellow, sweet and edible. It is almost odourless and possesses an appreciable test [4].

Moringa is called the "Miracle Tree" for good reason. Moringa leaves, pods, flowers, fruits, roots, bark, and seeds can be utilized in water treatment, as food supplement and the extract can be used against bacterial or fungal skin infections. It is estimated that at least three hundred diseases can be cured by taking this supplement along with hundreds of other health benefits, it contain more than 90 nutrients, different antioxidants, and all eight essential amino acids [5]. Moringa is rich in many vitamins, including vitamin A, several forms of vitamin $\mathrm{B}$, vitamin $\mathrm{C}$, vitamin $\mathrm{D}$ and vitamin $\mathrm{E}$. In fact, it has more of these vitamins than a variety of foods (such as carrots, oranges and milk) that claim to be excellent source of these vitamins [6]. The Moringa tree grows quickly in many types of soil environments. Much of the plant is edible by humans or by farm animals. The leaves are rich in protein, vitamin A, vitamin B, C and minerals [5]. Moringa leaves can be used in food preparation and also brewed as a tea, either alone or in combination with milk.

The term heavy metal refers to any metallic chemical element that has a relatively high density and may be toxic or poisonous even at low concentrations [7]. Heavy metals include zinc, lead, calcium, mercury etc. Heavy metals are natural components of the earth crust. They cannot be degraded or destroyed. To a small extent they enter our bodies via food, drinking water \& air. As trace elements, some heavy metals (e.g. Cu, $\mathrm{Zn}$, $\mathrm{Fe}$ ) are essential for maintaining the human body metabolism. There are several sources of metal poisoning which include water contamination via lead pipes, food contamination and inhalation of contaminated dust.

Heavy metals are dangerous, because they tend to bio accumulate. Bio accumulation means an increase in the content of a chemical in a biological organism over time, compared to the chemicals content in the environment. Diverse amounts of heavy metals may be found everywhere in soil, water, air, sediments, plants etc. chemicals like heavy metals once introduced to the environment by one particular method may spread to various environmental components which may be caused by the nature of interactions occurring in this natural system. Heavy metals may chemically or physically interact with the natural compounds, which change their forms of existence in the environment. Soil variability and some environmental properties (e.g. climatic factors) 
may change equilibrium found in the soil and cause leaching of trace toxic demerits like heavy metals tightly bound to soil particles [8]. The environment contains a wide range of heavy metals with varying concentration ranges depending on the surrounding geological environment and natural activities occurring or that has once occurred. These heavy metals can be $\mathrm{Fe}, \mathrm{Zn}, \mathrm{Cr}, \mathrm{Cd}, \mathrm{Pb}, \mathrm{Ni}, \mathrm{Mn}, \mathrm{Hg}$, etc. However, some heavy metals like $\mathrm{Pb}$, $\mathrm{Zn}, \mathrm{Cd}, \mathrm{Hg}$ and $\mathrm{Th}$ are of great concern because of their potential effects on human health, agriculture and environment. In this study, proximate nutritional analysis and heavy metal accumulation in moringa oleifera leaves were investigated using standard analytical techniques.

\subsection{Sampling}

\section{Materials And Methods}

Fresh leaves of Moringa Oleifera were plucked from the Moringa tree growing at Egbooda Oshiri. The leaves was removed from leaf branches, spread on a clean plastic tray and air dried at room temperature for 3 weeks until no trace of water was found in it. This was done to avoid interference during analysis and also to reduce the level of water content.

\subsection{Pretreatment}

Moringa Oleifera leaves were ashed at $550^{\circ} \mathrm{C}$ overnight and the ash was dissolved in concentrated $\mathrm{HNO}_{3}$, filtered and then diluted to $250 \mathrm{ml}$ with deionized water and the absorbance of the samples read directly on the spectrophotometer.

\subsection{Proximate analysis}

The proximate compositions of the dried Moringa leaves were determined using standard analytical methods. All measurements were done in duplicates and values presented in percentage.

\subsubsection{Ash content determination}

The ash content was determined using the method described in AOAC [9].

$5 \mathrm{~g}$ of the sample was weighed into a crucible in a muffle furnace and heated at $550^{\circ} \mathrm{C}$ for six hours until it became gray ash. The dish was removed from the muffle furnace using crucible tong and placed in a desiccator to cool. When cooled it was re-weighed and the weight of ash was obtained by the difference.

\subsubsection{Moisture content determination}

The moisture content of the samples was determined using AOAC method [9].

The Petri-dish was washed thoroughly and placed in oven to dry. $5 \mathrm{~g}$ of the sample was then placed in a preweighed Petri dish, and then placed in an oven to dry at $105^{\circ} \mathrm{C}$ for two hours. The dish and dry sample were transferred to a desiccator to cool at room temperature before being weighed again. The experiments were repeated until constant weight was obtained.

\subsubsection{Fat content determination}

Fat was determined using soxhlet fat extraction method [10].

$250 \mathrm{ml}$ boiling flask was washed thoroughly and dried in oven at $105^{\circ} \mathrm{C}$ for 30 minutes and then placed in a desiccator to cool. $2 \mathrm{~g}$ of the dried sample was then weighed accurately into labeled thimbles. Cooled boiling flask was filled with $200 \mathrm{ml}$ of petroleum ether and boiled at $40-60^{\circ} \mathrm{C}$. The extraction thimble was plugged lightly with a cotton wool and the boiling flask containing the petroleum ether was placed in the extraction thimble to boil and the soxhlet apparatus was allowed to reflux for six hours. The thimble was removed carefully, and the petroleum ether on top of the container was collected and drained into another container for reuse. When the flask was free of petroleum ether, it was removed and boiled for an hour at $105^{\circ} \mathrm{c}$. It was finally transferred from the oven into a desiccator to cool before weighing.

\subsubsection{Fibre content determination}

Crude Fibre content was determined by Weende's method [11].

$2 \mathrm{~g}$ of the sample was weighed into a $250 \mathrm{ml}$ conical flask and $200 \mathrm{ml}$ of $1.25 \% \mathrm{H}_{2} \mathrm{SO}_{4}$ was added and the mixture was boiled under reflux for 30minutes. The solution was filtered with whatman filter paper; the residue was rinsed thoroughly with hot water until it was no more acidic when tested using $\mathrm{pH}$ paper. The residue was transferred into a $250 \mathrm{ml}$ beaker and $200 \mathrm{ml}$ of $1.25 \% \mathrm{NaOH}$ was added and boiled for 30minutes in a digestion apparatus after which it was filtered and rinsed with distilled water until the filtrate was neutral when tested with $\mathrm{pH}$ paper. The residue was transferred into a crucible and placed in electric oven at $100^{\circ} \mathrm{C}$ for eight hours to dry. It was then removed and placed in a desiccator to cool before weighing. After weighing, the sample was incinerated, cooled in a desiccator and reweighed. 


\subsubsection{Protein determination}

Protein content of the sample was determined using the Kjeldahl method [12]. The total nitrogen was determined and multiplied by a conversion factor of 6.25 to obtain the protein content.

$0.5 \mathrm{~g}$ of the sample was weighed into a Kjeldahl digestion flask. A tablet of selenium catalyst was added to it. $20 \mathrm{ml}$ of $\mathrm{H}_{2} \mathrm{SO}_{4}, 10 \mathrm{~g}$ of $\mathrm{NaSO}_{4}, 1 \mathrm{~g}$ of $\mathrm{CuSO}_{4}$ were also added to the flask and digested by heating under a fume cupboard till the solution digested completely and changed to blue color. The solution was carefully removed and allowed to solidify for $24 \mathrm{hrs}$ until a white colour was obtained. The solution was dissolved with $100 \mathrm{ml}$ of distilled water in a $200 \mathrm{ml}$ volumetric flask. Then $60 \mathrm{ml}$ of $40 \%$ of $\mathrm{NaOH}$ and two pieces of zinc metal were added to the solution in the Kjeldahl distillation apparatus. The mixture was distilled until a total of $50 \mathrm{ml}$ distillate was collected into $250 \mathrm{ml}$ conical flask containing boric acid and was titrated with $0.1 \mathrm{~N}_{2} \mathrm{SO}_{4}$. The end point of the titration was observed when the color of the distillate changed to the initial color of the mixture of boric acid and screen methyl red indicator which was light pink.

\subsubsection{Carbohydrate determination}

The carbohydrate content of the test sample was determined by estimation using the arithmetic difference method [12].

$\% \mathrm{CHO}=100-(\%$ fat. $+\%$ ash $+\%$ fiber $+\%$ protein $)$

\subsection{Heavy metal analysis}

The heavy metals content of dried Moringa leaves was determined using AOAC method [13] and EDTA titrimetric method [9]. All determinations were done in duplicates and values of heavy metals were reported in $\mathrm{Mg} / \mathrm{L}$.

\subsubsection{Determination of Zinc}

This was determined by EDTA titrimetric method [9]. $2 \mathrm{ml}$ of sample solution was measured into a conical flask and $2 \mathrm{ml}$ of buffer solution was added to it. Then, 2 drops of Eriochrome Black $\mathrm{T}$ Indicator was added and the mixture titrated with 0.01 EDTA until the color changed from wine red to blue.

\subsubsection{Determination of Lead}

The Lead content in the sample was determined using spectrophotometric method [13]. 10ml of the sample solution was measured into a beaker, followed by addition of 5 drops of $10 \% \mathrm{KCN}, 5 \mathrm{ml}$ of $1.2 \mathrm{M} \mathrm{NH}$ solution and $5 \mathrm{ml}$ of $10 \% \mathrm{NaSO}_{4}$. The resulting mixture was made up to the $50 \mathrm{ml}$ with distilled water. The spectrophotometer was set at wavelength of $430 \mathrm{~nm}$ after calibration and the absorbance reading of the sample solution taken.

\subsubsection{Determination of Iron}

To determine the iron content, $5 \mathrm{ml}$ of the sample was pipetted into a $50 \mathrm{ml}$ of volumetric flask. $5 \mathrm{ml}$ of $17 \% \mathrm{CH}_{3} \mathrm{COONa}$ was then measured into the digested sample in a volumetric flask followed by addition of $0.5 \mathrm{ml}$ of $10 \%$ hydroxylamine hydrochloride and $5 \mathrm{ml}$ of $0.25 \% \mathrm{O}$-phenanthroline. Then the mixture was made up to $50 \mathrm{ml}$ with distilled water and allowed to develop for $30 \mathrm{mins}$ before the absorbance reading was taken using spectrophotometer. The wavelength of spectrophotometer was set at 510nm for iron [13].

\subsubsection{Determination of Copper}

To determine the copper content, $10 \mathrm{ml}$ of the digested sample was measured into $50 \mathrm{ml}$ of volumetric flask. $10 \mathrm{ml}$ of $0.01 \mathrm{~N} \mathrm{NH}_{4} \mathrm{OH}$ was added to the solution and the resultant mixture made up to $50 \mathrm{ml}$ using distilled water. It was allowed to develop for 30mins, before absorbance reading was taking with aid of the spectrophotometer at wavelength of $620 \mathrm{~nm}[13]$.

\subsubsection{Determination of Manganese}

Manganese content was determined by using the spectrophotometer. $20 \mathrm{ml}$ of the digested sample was measured into $50 \mathrm{ml}$ volumetric flask, then $5 \mathrm{ml}$ of phosphorus and $0.3 \mathrm{~g}$ of potassium periodate were added and the mixture shaked before boiling for $15 \mathrm{mins}$. It was allowed to cool before diluting with distilled water to make up to the $50 \mathrm{~m}$ mark on the standard flask. The resultant solution was then allowed to develop for $30 \mathrm{mins}$. The absorbance of the solution was read using the spectrometer machine at wavelength of 520nm [13].

\subsubsection{Determination of Cadmium}

Cadmium determination was carried out by EDTA titrimetric method using Xylenol Orange as an indicator. $25 \mathrm{ml}$ of the sample was measured into a $250 \mathrm{ml}$ conical flask. Then $5 \mathrm{ml}$ of distilled water, 3 drops of xylenol orange indicator and 1 drop of dilute $\mathrm{H}_{2} \mathrm{SO}_{4}$ were added to the sample solution. Thereafter, the color 
turned to yellow and hexamine powder was added until the color changed to deep red. It was then titrated with $0.05 \mathrm{~m}$ EDTA until color change from deep red to initial yellow was observed.

\subsubsection{Determination of Calcium}

This was determined by ethylenediaminetetraaetic acid (EDTA) titrirmetric method [14]. 10ml of the digested sample was measured into a $250 \mathrm{ml}$ conical flask. A pinch of potassium cyanide, a pinch of hydroxylamine hydrochloride, $5 \mathrm{ml}$ of $10 \%$ potassium hydroxide were added and shaken gently until the solids dissolve. Then a pinch of indicator (Pattons \& Reader's reagent) was added and the mixture titrated with the 0.01M EDTA solution until the color changed from wine red to blue which is the end point.

\subsubsection{Determination of Magnesium}

Magnesium was determined using EDTA titrirmetric method [14]. 10ml of the digested sample was pipetted into $250 \mathrm{ml}$ conical flask, a pinch of $\mathrm{KCN}$, a pinch of hydroxyl ammonium chloride solution and $5 \mathrm{ml}$ of $10 \%$ potassium hydroxide were added and shaken gently until the solid dissolved. A pinch of Eriochrome black $\mathrm{T}$ indicator was added and the mixture was titrated with 0.01M EDTA solution until the wine red color changes to blue color which is the end point.

\section{Results And Discussions}

Table 1 shows the results of proximate analysis of dried Moringa Oleifera. The results indicated that dried Moringa leaves contained appreciable amount of crude protein content $(24.5 \pm 0.9 \%)$ making it to be a good source of supplementary protein for man and livestock, The results also showed that Moringa leaves contain nutritious compounds.

Table 1: Proximate contents of the analyzed sample

\begin{tabular}{ll}
\hline Parameter (\%) & Mean \pm S.E.M \\
\hline Moisture & $14.8 \pm 0.2$ \\
Fat & $4.5 \pm \pm 0.1$ \\
Crude Protein & $24.2 \pm 0.9$ \\
Crude Fibre & $17.3 \pm 0.2$ \\
Ash & $3.8 \pm 0.2$ \\
Carbohydrate & $50.4 \pm 0.2$ \\
\hline
\end{tabular}

\footnotetext{
* S.E.M=Standard error of the Mean
}

Other similar studies have reported different values for the protein content of moringa leaves ranging from 1640\% [15-23]. Appreciable level of crude in moringa leaves is acceptable as it prevents the occurrence of diseases thereby promoting good health [24].

The carbohydrate content of dried moringa leaves was $50.4 \pm 0.2 \%$.This value however differs from similar findings which recorded carbohydrate contents of $45.43 \%, 43.88 \%$ and $63.11 \%$ respectively [20, 23, 25].

Carbohydrate deficiency causes depletion of body tissues [24]. Sufficiency of Carbohydrate is however necessary for optimum functioning of the brain, heart, nervous, digestive and immune systems [24].

High content of moisture $(14.8 \pm 0.2 \%)$ in moringa leaves was recorded in this study which was relatively higher than that obtained in similar researches with moisture content values of $11.76 \%, 3.21 \%, 76.53 \%$ and $9.53 \%$ respectively [20, 23, 25-26].

Ash content of $3.82 \pm 0.2 \%$ was recorded in this study which was comparatively low when compared to values obtained in similar research with ash content values of 7.64\%, 7.93\%, 7.13\% and $10.64 \%$ respectively [20, 23, 25-26].

The variation in nutritional makeup of the dried moringa leaves analyzed in this study and that of other similar researches could be attributed to the difference in genetic makeup of the plant and varying climatic and soil factors.

Table 2 however shows that dried Moringa leaves contain high amounts of heavy metals. Iron content in the dried leaves of Moringa was $505 \pm 53.0 \mathrm{mg} / \mathrm{L}$, indicating that the leaves could be a potential source of $\mathrm{Fe}$ supplement for human and livestock. Fe is an essential trace element for normal functioning of the central nervous system and in the oxidation of carbohydrates, proteins and fats [27]. Iron is also a necessary component of hemoglobin and myoglobin for oxygen transport and cellular processes of growth and division [28]. 
Table 2: Heavy metals contents of analyzed dried Moringa leaves

\begin{tabular}{ll}
\hline Heavy metal & Mean \pm SEM $(\mathbf{m g} / \mathbf{L})$ \\
\hline Lead & $352 \pm 2.36$ \\
Zinc & $85811 \pm 0.384$ \\
Copper & $1.016 \pm 0.08$ \\
Cadmium & ND \\
Magnesium & $386 \pm 1.01$ \\
Iron & $505 \pm 53.0$ \\
Calcium & ND \\
Manganese & $79 \pm 1.188$ \\
\hline
\end{tabular}

\section{ND $=$ Not Detected}

The mean Fe content in the sample was $505 \mathrm{mg} / \mathrm{L}$ which was comparable to similar studies done with reported Fe values of $103.75 \mathrm{mg}, 490 \mathrm{mg}, 28.2 \mathrm{mg}, 107 \mathrm{ppm}, 318.81 \mathrm{ppm}$ and $870 \mathrm{mg}$ of Fe respectively in dried Moringa leaves [20, 23, 25, 28-30]. Thus, Iron which is commonly deficient in many plant-based diets was found in abundance in these cited works.

The presence of $\mathrm{Zn}$ in high amounts is of special interest in view of the importance of $\mathrm{Zn}$ in the diet of animals and humans. Result from this analysis showed higher levels of zinc $(85811 \mathrm{mg} / \mathrm{L} \pm 0.384)$ than a similar finding of $25.5 \mathrm{mg}$ in dried Moringa leaves [31]. Furthermore, related researches also reported the level of zinc in dried Moringa leaves as $148.54 \mathrm{mg}, 60 \mathrm{ppm}$ and $57.34 \mathrm{ppm}$ respectively [20, 23, 25]. Zinc is essential for the synthesis of DNA, RNA, insulin and function of several enzymes, zinc is also required for cell reproduction and growth especially the sperm cells [32].

The dried Moringa leaves contained $\mathrm{Cu}$, which is considered to have strong effects on the immune system. $\mathrm{Cu}$ content found in the sample was $1.016 \mathrm{mg}$. Other studies have reported variable $\mathrm{Cu}$ contents of $0.57 \mathrm{mg}, 0.143 \mathrm{mg}, 6.10 \mathrm{mg}, 5.73 \mathrm{ppm}$, and $4.66 \mathrm{mg}$ respectively [5, 20, 23, 27, 33].

The Mg content of dried Moringa leaves, from the result was $386.6 \pm 1.01 \mathrm{mg} / \mathrm{L}$. Mg is an essential element that the body required in relatively large quantities compared to other minerals as it plays an important role in the structure of skeleton and muscles. Other studies have reported variable contents of $\mathrm{Mg}$ in Moringa leave as $0.38 \mathrm{ppm}, 1.03 \mathrm{ppm}$ and $107.56 \mathrm{mg}$ respectively $[23,26,33]$.

Calcium which is required for normal growth, strong muscles and skeletal development was surprisingly not detected in the leaves. It is suspected that $\mathrm{Mg}$ and $\mathrm{Zn}$ probably displaced the elemental $\mathrm{Ca}$ in the leaves and consequently plays the role of $\mathrm{Ca}$ in the plant. This view was further strengthened by the high amount of $\mathrm{Mg}$ found in the leaves $(386.6 \mathrm{mg} / \mathrm{L})$. However other reports have it that the calcium content of dried Moringa leaves was $98.67 \mathrm{mg}, 2003 \mathrm{mg}, 3.65 \%, 2.47 \mathrm{ppm}, 1.91$ and $3.4 \%$ respectively [4-5, 20, 23, 26, 33].

Thus, Dried Moringa leaves are available as a good source of $\mathrm{Ca}$ to farm animals or humans. Cadmium was also not detected in the leave samples tested.

For the case of Mn, dried Moringa leaves had Mn content of $79.56 \pm 1.188 \mathrm{mg} / \mathrm{L}$ which was comparable to that obtained by other researchers in similar studies with Mn values of $13.55 \mathrm{mg} / \mathrm{L}, 86.80 \mathrm{mg} / \mathrm{L}$, $81.65 \mathrm{mg} / \mathrm{L}$ and $21.70 \mathrm{mg} / \mathrm{L}$ respectively $[26,23,33,20]$.

Lead was also found in the leaves of Moringa at very high value of $352.01 \pm 2.36 \mathrm{mg} / \mathrm{L}$. The elevated level of $\mathrm{Pb}$ observed was probably due to high large deposit of Galena $(\mathrm{PbS})$ and other $\mathrm{Pb}$ ores in Oshiri, Ebonyi State where the leaves were harvested. In addition, a similar study reported a $\mathrm{Pb}$ level of $2.96 \mathrm{mg} / \mathrm{L}$ in dried Moringa leaves investigated [23].

\section{Conclusion}

Proximate analysis results show that dried moringa leaves is a good source of important nutrients and thus, the plant might be explored as a viable supplement in both animal and human food. Other nutritional contents in moringa leaves not covered in this study and the possible roles of edaphic factors on the nutritional makeup of moringa plants are areas for further investigation in future research. Furthermore, the phytochemical constituents of moringa oleifera leaves can be further explored in the search for further uses of moringa plants as herbal remedies.

In addition, the variation in the heavy metal contents of Moringa leaves found in this study when compared to earlier studies may be due to climatic and edaphic factors, solvents used for the analysis, the cultivation method used and age of the plant. Furthermore, the leaves have been known to serve as a herbal tonic and for the maintenance of tissues and cell membranes [34].

\section{References}

[1] J.M. Dalziel, The Useful Plants of West Africa. Grown for Oversea Government and Administrations (London: 4 mill Bank, 1955) 186-88.

[2] F.R. Irvine, The woody Plants of Ghana with special references to their uses. $2^{\text {nd }}$ ed. (London: Oxford University Press, 1961$) 868$.

[3] D. Odee, Forest biotechnology research in drylands of Kenya: The development of Moringa Species, Dryland Biodiversity, 2, 1998, 7-12. 
[4] H.P.S. Makkar, K. Becker. Nutrient and anti-quality factors in different morphological parts of the Moringa oleifera tree, Journal of Agricultural Science, 128, 1997, 311-322.

[5] L.J. Fuglie, Combating Malnutrition with Moringa, in J. Lowell, L.J. Fuglie (Ed.), The Miracle Tree: The multiple attributes of Moringa (Wageningen, the Netherlands: CTA publication. 2006) 117-36.

[6] C.G. Zarkada, H.D. Voldeng and Y.K. Yu, Determination of the protein quality of three new northern adapted cultivars or common and mico types soya beans by amino acid analysis. Journal of Agricultural and Food Chemistry, 45, 1997, $1161-1168$.

[7] B.J Alloway and D.C. Ayres, Chemical principles of Environmental Pollution, $3^{\text {rd }}$ ed., (London: Blacker Academic and Professional Publishers, 1993) 201-202.

[8] APHA, Standard Methods for the Examination of Water and Waste water, 13 ${ }^{\text {th }}$ ed., (New York: American Public Health Association, 1971) 391-400.

[9] AOAC, Official Methods of Analysis of the Association of Official Analytical Chemists, 16 ${ }^{\text {th }}$ ed., (Arlington, Virginia: AOAC International, 1995)

[10] G.I. Onwuka, Food Analysis and Instrumentation: Theory and Practice (Lagos: Naphthali Prints, 2005) 1-219.

[11] C.S. James, Analytical Chemistry of Foods (New York: Blackie Academic and Professional, 996) 207-219.

[12] D.A. Pearson, The Chemical analysis of foods, $7^{\text {th }}$ ed. (Edinburgh: Churchill Livingstone, 1976).

[13] AOAC, Official Methods of Analysis of the Association of Official Analytical Chemists, $13^{\text {th }}$ ed. (Washington DC: AOAC International, 1980).

[14] F.J. Welcher, The Analytical uses of Ethylenediaminetetraacetic acid, (New York: D. Van Nostrand Company Inc., 1958).

[15] S.V. Sarwatt, M.S. Milang'ha, F.P. Lekule, N. Madalla, Moringa oleifera and cottonseed cake as supplements for smallholder dairy cows fed Napier grass, Livestock Research for Rural Development, 16(6), 2004, Article \#38.

[16] F.S. Nouala, O.O. Akinbamijo, A. Adewumi, E. Hoffman, S. Muetzel, K. Becker. The influence of Moringa Oleifera leaves as substitute to conventional concentrate on the in vitro gas production and digestibility of groundnut hay, Livestock Research for Rural Development, 18(9), 2006, 121.

[17] N. R. Sanchez, E. Sporndly, I. Ledin, Effects offeeding different levels of foliage of Moringa oleifera to creole dairy cows on intake, digestibility, milk production and composition, Livestock Science, 101 (1), 2006, 24-31.

[18] I. Oduro, W.O. Ellis, D. Owusu, Nutritional potential of two leafy vegetables: Moringa Oleifera and Ipomoea batata leaves, Science Research Essays 3(2), 2008, 57-60.

[19] D.I. Sanchez - Machado, J.A. Nunez-Gastelum, C. Reyes-Moreno, B. Ramirez-Wong, J. Lopenz-Cervantes, Nutritional quality of edible parts of Moringa Oleifera, Food Analytical Methods, 3, 2009, 175-180.

[20] A.O. Ogbe, P.A. John, Proximate study, mineral and anti-nutrient composition of Moringa oleifera leaves and potential benefits in poultry nutrition and health, Journal of Microbiology, Biotechnology and Food science, 1(3), 2011, 296-308.

[21] S.P. Davidson, J.F. Brock, A.S.I. Truswell, Human Nutrition and Dietetics, $6^{\text {th }}$ ed. (New York: Churchill Livingstone, 1975) 107224.

[22] P.M. Kris-Etherton, K.D. Hecker, A. Bonanome, S.M. Coval, A.E. Binkoski, K.F. Hilpert KF et al., Bioactive compounds in foods: their role in the prevention of cardiovascular disease and cancer, American Journal of Medicine, 113, 2002, 71-88.

[23] O.O. Anthonia, Evaluation of antimicrobial properties and nutritional potential of Moringa leaves in South-Western Nigeria, Malaysian Journal of Microbiology, 8(2), 2002, 59-67.

[24] M.M. Barker, Nutrition and Dietetics for Health care, $9^{\text {th }}$ ed. (New York: Churchill Livingstone, 1996) 92-101.

[25] P.N. Onu, A.O. Aniebo, Influence of Moringa oleifera meal on the performance and blood chemistry of starter broilers, Indian Journal of Fundamental and Applied Life Science, Vol.1 (1), 2011, 38-44.

[26] M. Busani, M.J. Patrick, H. Arnold, M. Voster, Nutritional characterization of Moringa leaves, African Journal of Biotechnology, 10(60), 2001, 12925-12933.

[27] S. Kozat, Serum T3 and T4 concentrations in lambs with nutritional myodegeneration, Journal of Veterinary Internal Medicine 21(5), 2007, 1135-1137.

[28] N. Foidl, H.P.S. Makkar, K. Becker. The potential of Moringa oleifera for agricultural and industrial uses, in J. Lowell, L.J. Fuglie (Ed.), The Miracle Tree: The multiple uses of Moringa (Wageningen, the Netherlands: CTA Publication. 2001) 45-76.

[29] National Research Council, Lost crops of Africa: Vegetables, Vol.2 (Washington D.C: National Academies Press, 2006) $246-267$.

[30] J.T. Barminas, M. Charles and D. Emmanuel, Mineral composition of non-conventional leafy vegetables. Plant Foods for Human Nutrition, 53(1), 1998, 29-36.

[31] E.A. Brisibe, U.E. Umoren, F. Brisibe, P.M. Magalhaes, J.F.S. Ferrerira, D. Luthria, X. Wu and R.L. Prior, Nutritional characterization and antioxidant capacity of different tissues of Artemisia annua L. Food Chemistry 115, 2009, 1240-1246.

[32] S.K. Mutayoba, E. Dierenfeld, V.A. Mercedes, Y. Frances and C.D. Knight, Determination and anti-nutritive components for Tanzanian locally available poultry feed ingredients, International Journal of Poultry Science, 10(5), 2011, $350-357$.

[33] M.M. Khalafalla, E. Abdellatef, H.M. Dafalla, A.A. Nassrallah, K.M. Aboul-Enein, D.A. Lightfoot, F.E. El-Deeb, H.A. ElShemy, Active principle from Moringa oleifera lam leaves effective against two leukemias and a hepatocarcinoma. African Journal of Biotechnology, 9(49), 2010, 8467-8471. 